\title{
Field Efficacy of a Combination of Seed Treatment and Foliar Spray against Pest Complex in Green Gram
}

\author{
V.K. Chaudhari, V.B. Patel, M.P. Patel, A.S. Bhanvadiya
}

10.18805/LR-4577

\begin{abstract}
Background: Pulses constitute the major source of dietary protein; therefore, it has ability to fulfil required protein recommended dietary allowance for vegetarian population of India. Pulse crop attack more than 200 insect pests and inflicting heavy damages at different growth stages that lead to significant economic losses to the farmers. The studies were conducted on green gram to find out the effective control measure of different crop stages against insect pests complex in green gram.

Methods: The field experiment was laid out in a randomized block design and the consist 12 treatments with seed treatment and foliar sprays of insecticides at 50 per cent flowering stages then these treatments were replicated thrice at both years 2017 and 2018. Result: The experiments concluded that the reduction of sucking pests population like thrips, jassid and whitefly and larval population of Maruca vitrata and Helicoverpa armigera was found in seed treated with imidacloprid 48 FS and spray of flubendiamide at 50 per cent flowering stage in green gram with Rs. 10,678 net profit and 1:1.42 cost-benefit ratio.
\end{abstract}

Key words: Foliar spray, Gram pod borer, Green gram, Seed treatment, Spotted pod borer.

\section{INTRODUCTION}

India has 29 per cent vegetarians, which was more than everywhere in the world. India has sufficient food grain to meet the recommended dietary allowance (RDA). However, per capita pulse availability and consumption have declined since 1975 consequently, nutrient intake RDA was insufficient, especially protein (Ramachandran, 2006). Pulses constitute the major source of dietary protein; therefore, it can fulfill required protein RDA for a vegetarian population of India.

India is the largest producer and consumer of pulses in the world account for 33 per cent of world's area and 24 per cent of world's production. Green gram is one of the thirteen food legumes grown in India among them third important legume after chickpea and pigeon pea.

There are more than 200 insect pests belong to 48 families attack on green gram and inflicting heavy damages at different growth stages in different agro-climatic conditions (Lal and Sachan, 1987). Among them sucking pests like aphid, jassid, whitefly, bugs thrips and caterpillar like spotted pod borer, hairy caterpillar, tobacco caterpillar and blue butter flies are key pests in Gujarat. The sucking insect pests not only reduce the vigor of the plant by sucking the sap but transmit diseases and affect photosynthesis consequently reduce yield. Yellow mosaic virus disease cause 67 per cent yield losses in green gram and black gram that transmitted by whitefly (Jain et al., 1995). Caterpillar damage reproductive parts like pods and cause significantly economical damage to the farmers. Several reports (Biswas and Bhunia, 2009; Khutwad et. al., 2002; Salam, 2005) shown the combination of the seed treatment and foliar spray against pest was more effective than alone spray and give complete protection against pest complex. Hence, the present studies were conducted on green gram to find out
Anand Agricultural University, Anand-388 110, Gujarat, India.

Corresponding Author: V.K. Chaudhari, Anand Agricultural University, Anand-388 110, Gujarat, India.

Email: vkcvaibhav@aau.in

How to cite this article: Chaudhari, V.K., Patel, V.B., Patel, M.P. and Bhanvadiya, A.S. (2021). Field Efficacy of a Combination of Seed Treatment and Foliar Spray against Pest Complex in Green Gram. Legume Research. DOI: 10.18805/LR-4577.

Submitted: 02-01-2021 Accepted: 15-04-2021 Online: 08-09-2021

the effective and economical insecticides as a seed treatment and a foliar spray combination against insect pests complex in green gram.

\section{MATERIALS AND METHODS}

The present study was conducted during kharif season year of 2017 and 2018 at Regional Research Station, Anand Agricultural University, Anand. The field experiment was laid out in a randomized block design (RBD) and the consist 12 treatments (Table 1) including control and these treatments were replicated thrice. Green gram variety GAM-5 which is commonly cultivated in this area was grown in plots had 5 rows, plot size $5.0 \times 3.6$ meter in each plot. The space between rows and plants were maintained $45 \mathrm{~cm}$ and 10 $\mathrm{cm}$, respectively. Crop was raised by following all local recommended agronomical practice except insecticidal spray.

For seed treatment, $200 \mathrm{~g}$ of green gram seeds was taken in a plastic bag. Then $10 \mathrm{ml}$ of water and required quantity of insecticide was added to this and stirred carefully. More water was added drop by drop and stirred well to get slurry. Plastic bag was tightened properly and vigorously shaken for 30 seconds to get uniform coated of the slurry on the seeds. Dressed seed was then air dried in shade 
overnight and sown on the next day. For foliar application, the treatment's wise application of insecticides were done at 50 per cent flowering of the green gram. Spray fluid was taken 500 liters per hectare. All sprays were done by using knapsack sprayer in the morning hours. To avoid cross contamination of insecticides, utmost care taken as spray pump was washed thrice with fresh water while switching over from one insecticide to another.

For the count of aphid, jassid and whitefly, 5 plants randomly selected in net plot area of each treatment. The population jassid and whitefly will be recorded from three leaves (upper, middle and lower) of the selected plants. The data from each plot were recorded early in the morning at every week after 10 days of sowing up to 60 days after sowing for sucking pest. The observations of the number of larvae per plant were recorded on one day before and $1^{\text {st }}$, $3^{\text {rd }}$ and $7^{\text {th }}$ day after spray from randomly selected 5 plants per plot. At the time of harvest, pod damage was recorded from randomly selected 50 pods from each plot.

The data was analyzed of variance to determine the significance of treatments (Steel and Torrie, 1980). Means were separated by Duncan's New Multiple Range Test (DMRT) (Duncan, 1955).

\section{RESULTS AND DISCUSSION}

\section{Effect of seed treatment}

Sucking pest population viz. thrips, jassid and whitefly on green gram at 10 to 60 day after sowing (DAS) was homogeneous in treatments indicated uniformly distribution in the experimental plot during kharif 2017 and 2018. The data of 10 to 60 DAS were analyzed and presented in Table 2.

Green gram seeds treated with imidacloprid $48 \mathrm{FS}$ and thiamethoxam $30 \mathrm{FS}$ which were $\mathrm{T}_{1}, \mathrm{~T}_{2}, \mathrm{~T}_{3}, \mathrm{~T}_{4}, \mathrm{~T}_{5}, \mathrm{~T}_{6}, \mathrm{~T}_{7}$ and $\mathrm{T}_{8}$ found significantly reduce a population of thrips compare to $\mathrm{T}_{9}, \mathrm{~T}_{10}, \mathrm{~T}_{11}$ and control in 2017. In 2018, significantly lowest thrips population was observed in seed treated with imidaclopriod $48 \mathrm{FS}$, which were $\mathrm{T}_{1}, \mathrm{~T}_{2}, \mathrm{~T}_{3}, \mathrm{~T}_{7}$ followed by seed treated with thiomethoxam $30 \mathrm{FS}$ which was $\mathrm{T}_{4}, \mathrm{~T}_{5}, \mathrm{~T}_{6}$ and $T_{8}$. The data on pooled over year revealed that, significantly lowest thrips population was observed in seed treated with imidacloprid $48 \mathrm{FS}$, which were $\mathrm{T}_{1}, \mathrm{~T}_{2}, \mathrm{~T}_{3}$ and $\mathrm{T}_{7}$ followed by seed treated with thiomethoxam $30 \mathrm{FS}$, it was $\mathrm{T}_{5}$ and $\mathrm{T}_{6}$ (Table 2).

The pooled over periods data in 2017, indicate jassid population found significantly lowest in seed treated with imidacloprid $48 \mathrm{FS}$, which were $\mathrm{T}_{1}, \mathrm{~T}_{2}, \mathrm{~T}_{3}$ and $\mathrm{T}_{7}$ followed by seed treated with thiomethoxam $30 \mathrm{FS}$, that was $\mathrm{T}_{4}, \mathrm{~T}_{5}$ and $\mathrm{T}_{6}$. In 2018, significantly lowest jassid population was observed in seed treated with imidaclopriod $48 \mathrm{FS}\left(\mathrm{T}_{1}, \mathrm{~T}_{2}\right.$, $\mathrm{T}_{3}$ and $\left.\mathrm{T}_{7}\right)$ and thiamethoxam $30 \mathrm{FS}\left(\mathrm{T}_{4}, \mathrm{~T}_{5}, \mathrm{~T}_{6}\right.$ and $\mathrm{T}_{8}$ compared to $T_{9}, T_{10}, T_{11}$ and control. The data of pooled over year revealed that the significantly lowest jassid population was found in seed treated with imidacloprid 48 FS which were $T_{1}, T_{2}, T_{3}$ and $T_{7}$ followed by seed treated with thiomethoxam $30 \mathrm{FS}$, it was $\mathrm{T}_{4}, \mathrm{~T}_{5}, \mathrm{~T}_{6}$ and $\mathrm{T}_{8}$ (Table 2).

Whitefly population was found significantly lowest in 


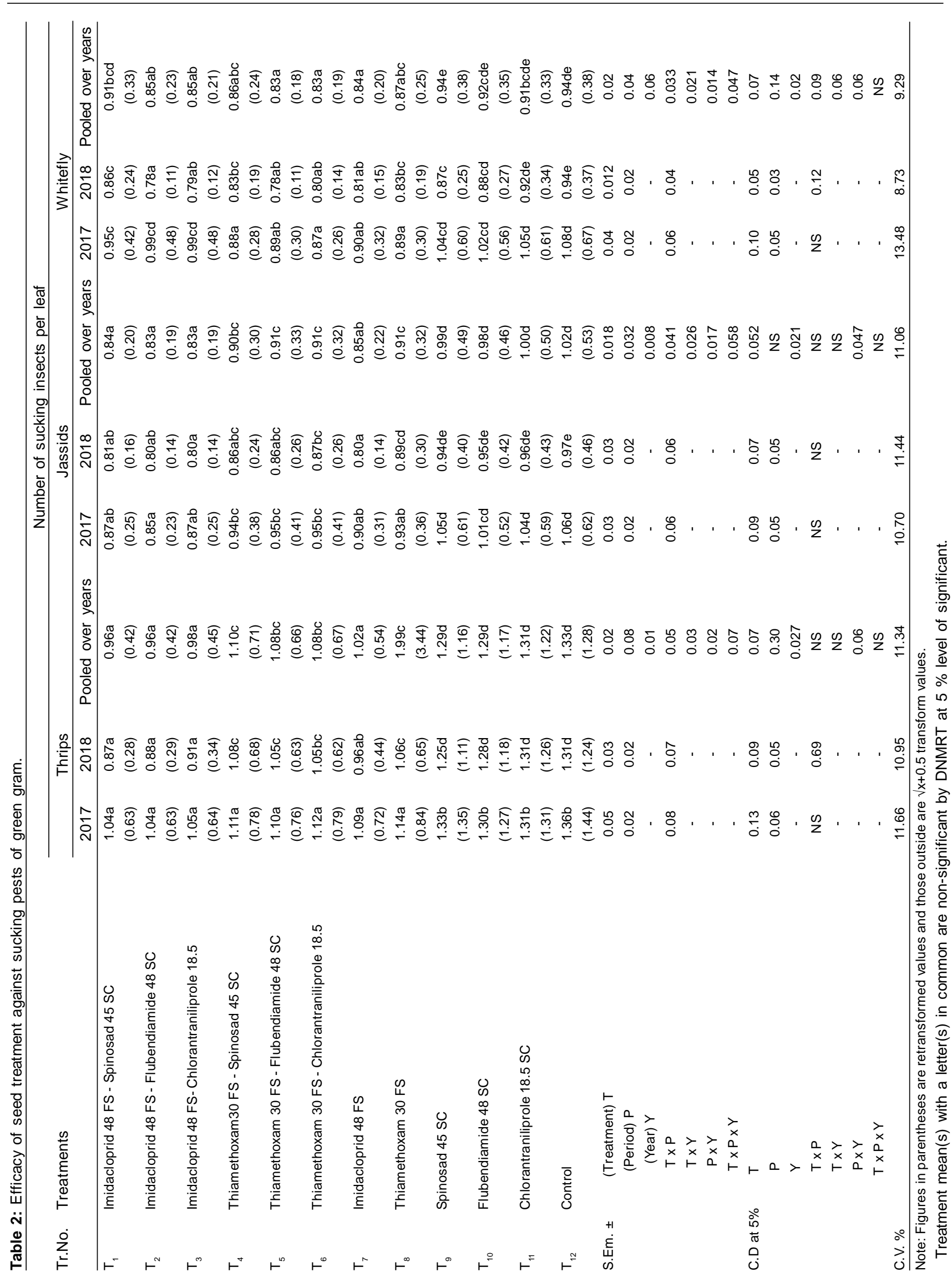


seed treated with thiamethoxam $30 \mathrm{FS}$, which were $T_{4}, T_{5}$, $T_{6}$ and $T_{8}$ in 2017. At 2018, significantly lowest whitefly population was observed in thiomethoxam $\left(T_{5}, T_{6}\right.$ and $\left.T_{7}\right)$ and imidacloprid $\left(T_{1}\right.$ and $T_{3}$ ). The pooled over year data indicated that significantly lowest whitefly population was observed in seed treated with imidacloprid $48 \mathrm{FS}\left(\mathrm{T}_{2}, \mathrm{~T}_{3}\right.$ and $\left.T_{7}\right)$ and thiamethoxam $30\left(T_{4}, T_{5}, T_{6}\right.$ and $\left.T_{8}\right)$.

The results obtained from the present study revealed that the seed treatment with imidacloprid48 FS@5.0 ml/ $\mathrm{kg}$ was found more effective against thrips, jassid and whiteflies in green gram. The present findings are in accordance with many of the earlier reports. The seed treated with imidacloprid 48 FS @ $5.0 \mathrm{ml} / \mathrm{kg}$ followed by foliar spray with either of the neonicotiniods such as thiamethoxam 25 WG or acetameprid 20 SP were found effective against both the thrips and whiteflies in greengram (Mahalakshmi, et al., 2018). Seed treated with thiomethoxam 25 WG @ 0.0035\% and imidacloprid 70 WS @ 0.0035\% which was protecting the greengram from whiteflies up to 25 days after sowing (Panduranga et al., 2011). Seed treated with imidacloprid 600 FS @ $10 \mathrm{ml} / \mathrm{kg}$ found significantly lowest population of whitefly, leafhopper and thrips with highest gross and net returns (Anusha et al., 2016).

\section{Effect of spray at $\mathbf{5 0}$ per cent flowering}

The larval population of pod borar viz. spotted pod borer (Maruca vitrata), gram pod borer (Helicoverpa armigera) found non-significant difference before the spray of insecticides on treatments.

During 2017, the data of pooled over periods indicated that the significantly lowest larval population was found in spray with spinosad $45 \mathrm{SC}\left(\mathrm{T}_{1}\right)$, it was at par with all spray treatments viz. flubendiamide $48 \mathrm{SC}\left(\mathrm{T}_{2}, \mathrm{~T}_{5}\right.$ and $\left.\mathrm{T}_{10}\right)$ and chlorantraniliprole 18.5 SC $\left(\mathrm{T}_{3}, \mathrm{~T}_{6}\right.$ and $\left.\mathrm{T}_{11}\right) \cdot \ln 2018$, the data of pooled over periods indicated that significantly lowest larval population was found in spray with flubendiamide 48 SC $\left(\mathrm{T}_{5}\right)$ and chlorantraniliprole 18.5 SC $\left(\mathrm{T}_{6}\right)$. During 2017, the data of pooled over periods indicated significantly lowest larval population was found in spray with spinosad 45 SC $\left(T_{1}\right)$, it was at par with all spray treatment viz. flubendiamide $48 \mathrm{SC}\left(\mathrm{T}_{2}, \mathrm{~T}_{5}\right.$ and $\left.\mathrm{T}_{10}\right)$ and chlorantraniliprole 18.5 SC $\left(\mathrm{T}_{3}\right.$, $T_{6}$ and $\left.T_{11}\right)$. In 2018, the data of pooled over periods indicated that significantly lowest larval population was found in spray with flubendiamide $48 \mathrm{SC}\left(\mathrm{T}_{5}\right)$ and chlorantraniliprole 18.5 SC $\left(T_{6}\right)$. The pooled over years, data revealed that the significantly lowest larval population was observed in spray with flubendiamide $48 \mathrm{SC}\left(\mathrm{T}_{2}, \mathrm{~T}_{5}\right.$ and $\left.\mathrm{T}_{10}\right)$ and chlorantraniliprole 18.5 SC $\left(\mathrm{T}_{3}, \mathrm{~T}_{6}\right.$ and $\left.\mathrm{T}_{11}\right)$ (Table3).

The data clearly stated that flubendiamide $48 \mathrm{SC}$ and chlorantraniliprole 18.5 SC were highly effective against Maruca vitrata. These find also confirm by Mallikarjuna (2009) the highest larval reduction of pod borers with flubendiamide 480 SC and thiacloprid 48 SC followed by emamectin benzoate $55 \mathrm{G}$ and indoxacarb $14.5 \mathrm{SC}$ in dolichos bean. Mahalakshmi et al. (2013) reported that coragen 20\% SC (chlorantranilip- role) at $20 \mathrm{~g}$ a.i./ha proved highly effective against the larval population of Maruca vitrata in blackgram.
During 2017, significantly lowest gram pod borer (Helicoverpa armigera) larval population was observed in spray with spinosad $45 \mathrm{SC}\left(\mathrm{T}_{1}, \mathrm{~T}_{4}\right.$ and $\left.\mathrm{T}_{9}\right)$, flubendiamide $48 \mathrm{SC}\left(\mathrm{T}_{2}, \mathrm{~T}_{5}\right.$ and $\left.\mathrm{T}_{10}\right)$ and chlorantraniliprole $18.5 \mathrm{SC}\left(\mathrm{T}_{3}, \mathrm{~T}_{6}\right.$ and $\left.T_{11}\right)$ compared to control $\left(T_{12}\right)$ and only seed treatment $\left(T_{7}\right.$ and $\left.T_{8}\right)$. In 2018, pooled over periods data indicated that significantly lowest larval population was observed in spray with spinosad 45 SC and chlorantraniliprole 18.5 SC which was $T_{2}, T_{8}$ and $T_{3}, T_{11}$, respectively. The pooled over year data indicated that significantly lowest larval population was observed in spray with spinosad $45 \mathrm{SC}\left(\mathrm{T}_{1}, \mathrm{~T}_{4}\right.$ and $\left.\mathrm{T}_{9}\right)$, flubendiamide $48 \mathrm{SC}\left(\mathrm{T}_{2}, \mathrm{~T}_{5}\right.$ and $\left.\mathrm{T}_{10}\right)$ and chlorantraniliprole 18.5 SC $\left(T_{3}, T_{6}\right.$ and $\left.T_{11}\right)$ compared to control $\left(T_{12}\right)$ and only seed treatment $\left(T_{7}\right.$ and $\left.T_{8}\right)$ (Table 4). The current findings are also supported previously a finding by Kumar and Shivaraju (2009) that reported thiodicarb 75 WP @ 562.5g a.i/ha and flubendiamide 480 SC @ $48 \mathrm{~g}$ a.i/ha were highly effective for control the pod borers in blackgram.

\section{Pod damage}

At harvest stage, significantly lowest pod damage was recorded in spray at 50 per cent flowering with flubendiamide $48 \mathrm{SC}\left(\mathrm{T}_{2}, \mathrm{~T}_{5}\right.$ and $\left.\mathrm{T}_{10}\right)$ which was at par with chlorantraniliprole $18.5 \mathrm{SC}\left(\mathrm{T}_{3}\right.$ and $\left.\mathrm{T}_{6}\right)$. In 2018, the significantly lowest pod damage was recorded in spray at 50 per cent flowering with flubendiamide $48 \mathrm{SC}\left(\mathrm{T}_{2}, \mathrm{~T}_{5}\right.$ and $\left.\mathrm{T}_{10}\right)$ which, was at par with chlorantraniliprole $18.5 \mathrm{SC}\left(\mathrm{T}_{3}\right.$ and $T_{6}$ ). The pooled over year data revealed that significantly lowest pod damage was recorded in spray at 50 per cent flowering with flubendiamide $48 \mathrm{SC}\left(\mathrm{T}_{2}, \mathrm{~T}_{5}\right.$ and $\left.\mathrm{T}_{10}\right)$, it was at par with chlorantraniliprole 18.5 SC ( $\mathrm{T}_{3}$ and $\mathrm{T}_{6}$ ) (Table 5). These finding also supported previously reported by Mahalakshmi et al. (2013) that coragen $20 \%$ SC (chlorantraniliprole) at $20 \mathrm{~g}$ a.i./ha proved highly effective against pod borer and less pod damage was observed in black gram.

\section{Yield}

The yield of green gram grain was found the significant highest in all combination of seed treated (imidacloprid 48 FS and thiomethoxam $30 \mathrm{FS}$ ) and spray at 50 per cent flowering (spinosd $45 \mathrm{SC}$, flubendiamide $48 \mathrm{SC}$ and chlorantraniliprole 18.5 SC) which was $T_{1}, T_{2}, T_{3}, T_{4}$ and $T_{5}$ in 2017. The lowest green gram grain yield was $652 \mathrm{~kg}$ per hector was obtained in control. During 2018, the significantly highest green gram grain yield was observed in seed treated with imidacloprid $48 \mathrm{FS}$ and spray at 50 per cent flowering with chlorantraniliprole $18.5 \mathrm{SC}\left(\mathrm{T}_{3}\right)$ which was at par with seed treated with imidacloprid 48 FS and spray with flubendiamide 48 SC $\left(T_{2}\right)$ and seed treated with thiamethoxam $30 \mathrm{FS}$ and spray with chlorantraniliprole 18.5 SC $\left(T_{5}\right)$. The pooled over year data indicated that significantly highest yield was observed in seed treated with imidacloprid and thiomethoxam and spray at 50 per cent flowering with spinosd $45 \mathrm{SC}$, flubendiamide $48 \mathrm{SC}$ and chlorantraniliprole $18.5 \mathrm{SC}$, which was $\mathrm{T}_{1}, \mathrm{~T}_{2}, \mathrm{~T}_{3}, \mathrm{~T}_{4}$ and $\mathrm{T}_{5}$. The lowest green gram grain yield was $770 \mathrm{~kg}$ per hector observed in control 


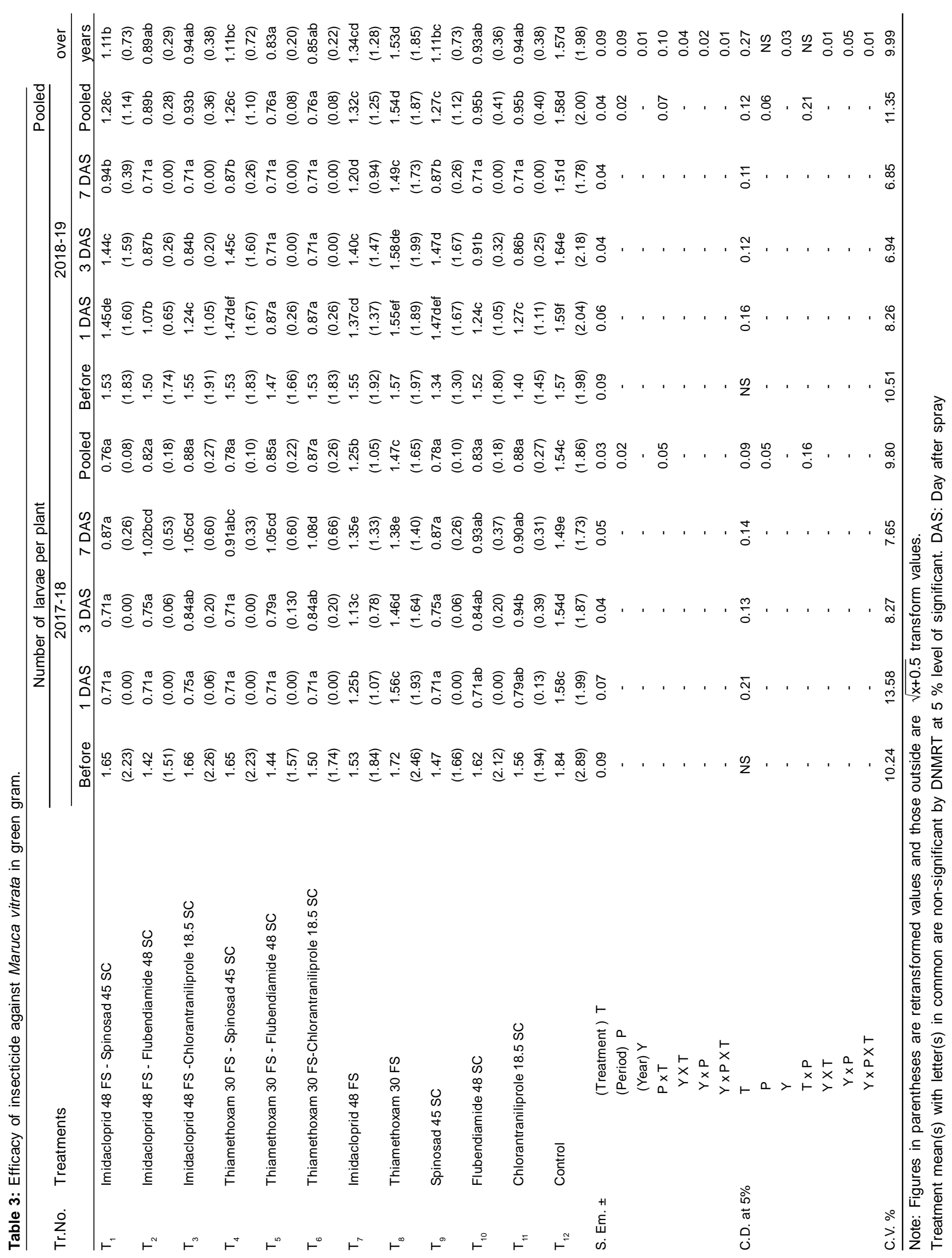




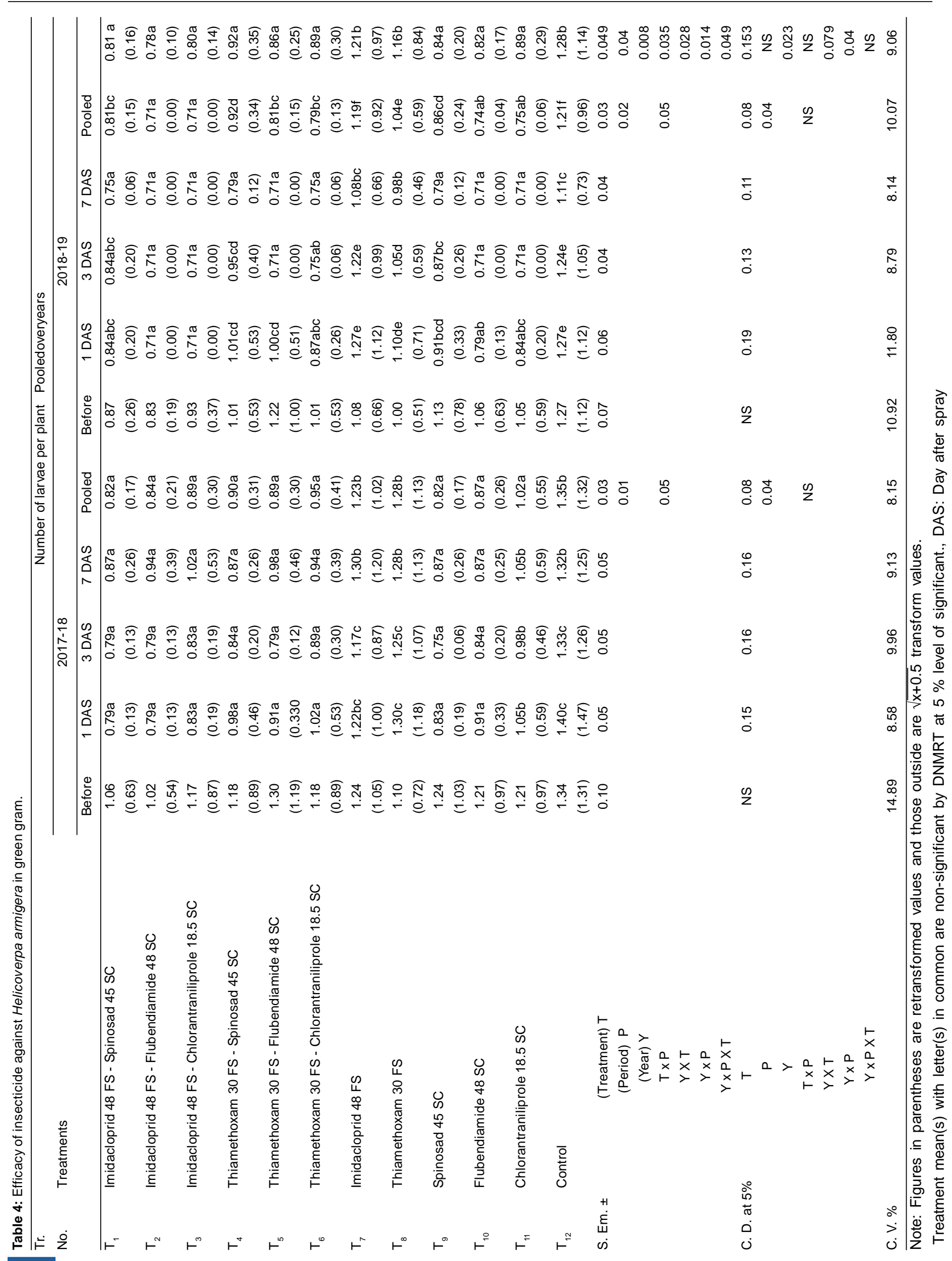




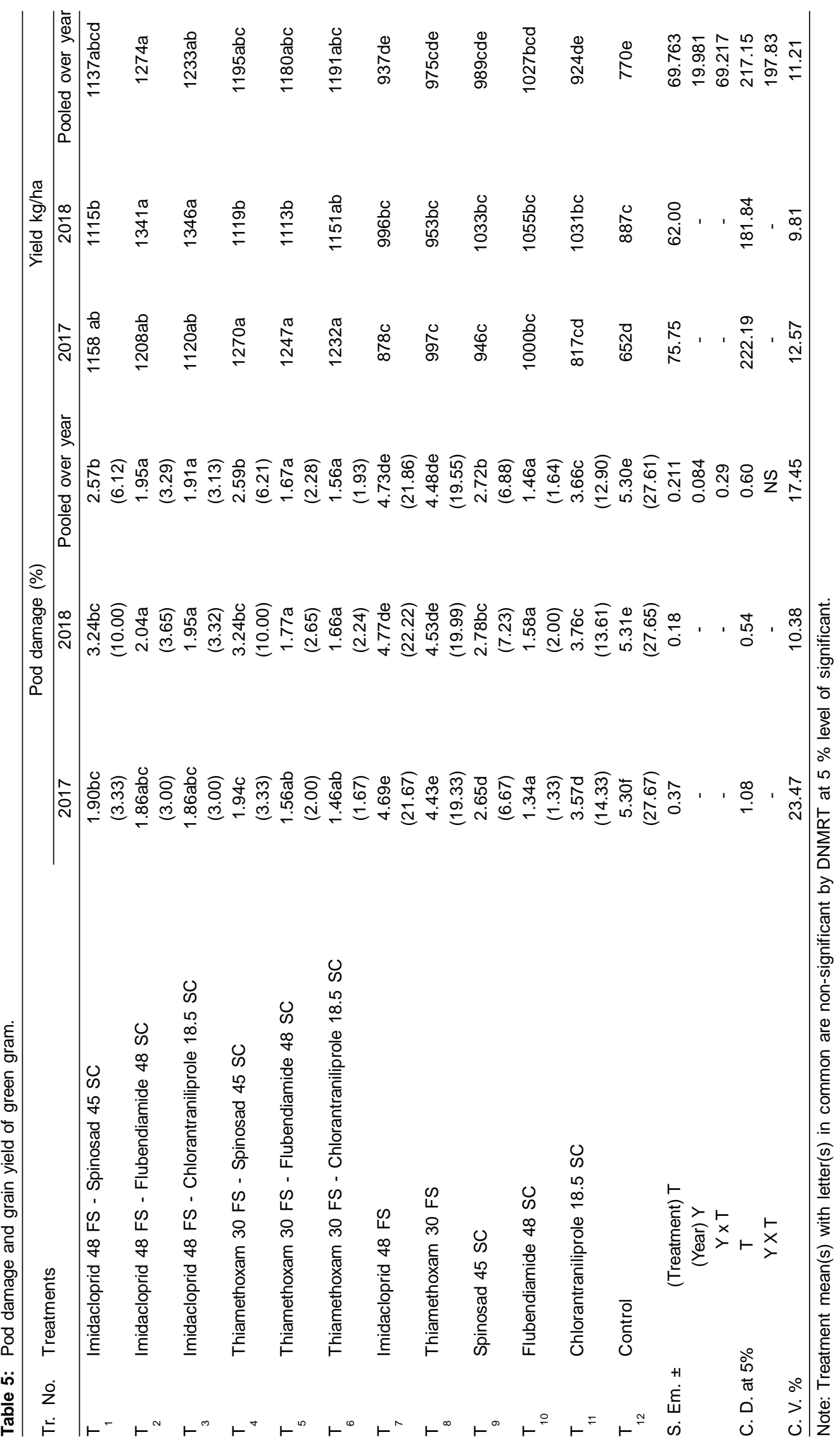




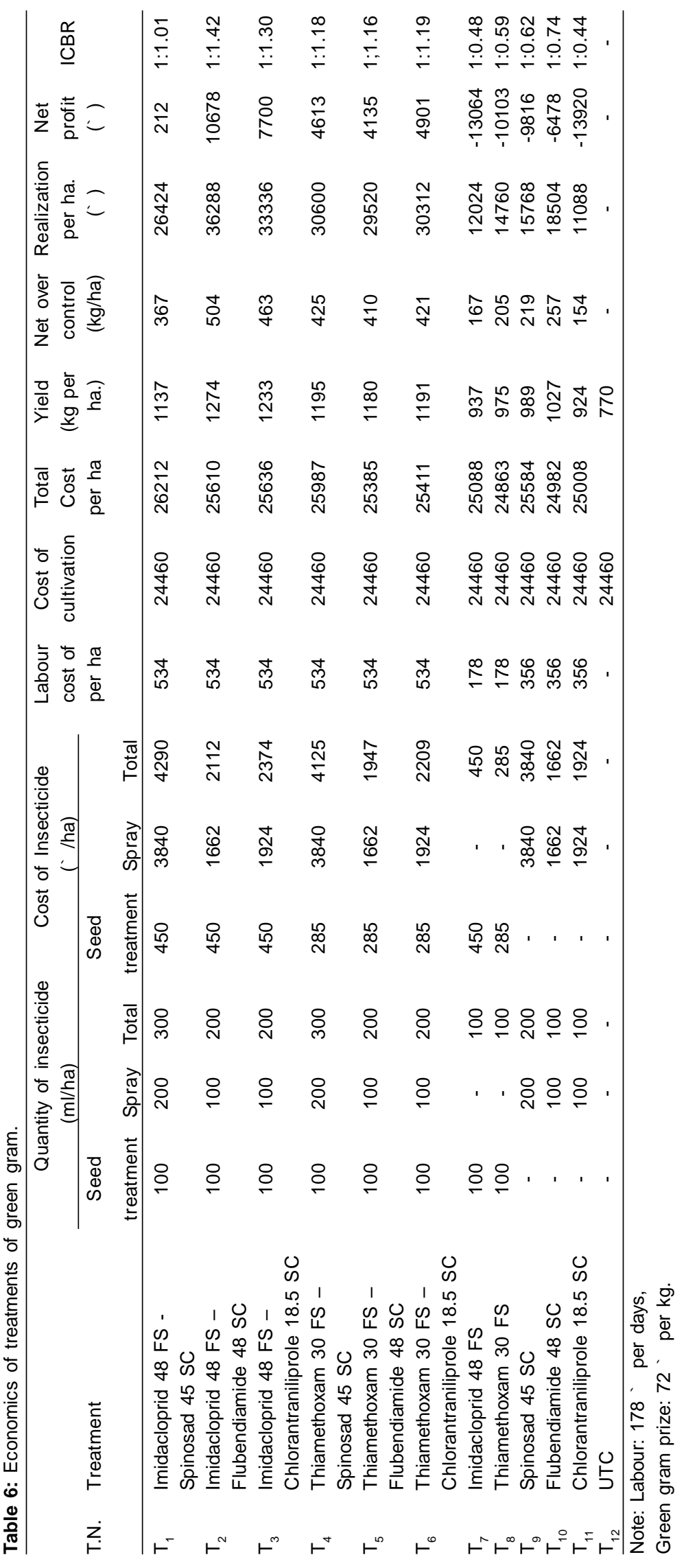


treatment. All combination treatment which was seed treated with imidacloprid $48 \mathrm{FS}$, thiomethoxam $30 \mathrm{FS}$ and spray with spinosd $45 \mathrm{SC}$, flubendiamide $48 \mathrm{SC}$ and chlorantraniliprole $18.5 \mathrm{SC}$ at 50 per cent flowering were found highly effective against insect pests and which was reflected on greengram yield (Table 5).

\section{Economics}

The perusal of the data (Table 6) indicated that the highest net profit of Rs. 10,678/ ha was obtained from $\mathrm{T}_{2}$ (seed treated with imidacloprid $48 \mathrm{FS}$ and spray with flubendiamide $48 \mathrm{SC}$ ) followed by $\mathrm{T}_{3}$ (seed treated with imidacloprid $48 \mathrm{FS}$ and spray with chlorantraniliprole $18.5 \mathrm{SC}$ ), $\mathrm{T}_{6}$ (seed treated with thiamethoxam $30 \mathrm{FS}$ and spray with chlorantraniliprole 18.5 SC), $\mathrm{T}_{4}$ (seed treated with thiamethoxam $30 \mathrm{FS}$ and spray with spinosad $45 \mathrm{SC}$ ), $\mathrm{T}_{5}$ (seed treated with thiamethoxam $30 \mathrm{FS}$ and spray with flubendiamide $48 \mathrm{SC}$ ), $\mathrm{T}_{1}$ (seed treated with imidacloprid 48 FS and spray with spinosad 45 SC) with net profits of Rs. 7,700, Rs. 4,901, Rs. 4,613, Rs. 4,135 Rs. 212, per hectare, respectively.

However, when viewed from the angle of cost- benefit ratio, a maximum profit of Rs. 1.42 per rupee invested was obtained in $\mathrm{T}_{2}$ (seed treated with imidacloprid $48 \mathrm{FS}$ and spray with flubendiamide $48 \mathrm{SC}$ ), $\mathrm{T}_{3}$ (seed treated with imidacloprid $48 \mathrm{FS}$ and spray with chlorantraniliprole 18.5 $\mathrm{SC}$ ), $\mathrm{T}_{6}$ (seed treated with thiamethoxam $30 \mathrm{FS}$ and spray with chlorantraniliprole $18.5 \mathrm{SC}$ ), $\mathrm{T}_{4}$ (seed treated with thiamethoxam $30 \mathrm{FS}$ and spray with spinosad), $\mathrm{T}_{5}$ (seed treated with thiamethoxam 30 FS and spray with flubendiamide $48 \mathrm{SC}$ ), $\mathrm{T}_{1}$ (seed treated with imidacloprid $48 \mathrm{FS}$ and spray with spinosad $45 \mathrm{SC}$ ), $\mathrm{T}_{10}$ (flubendiamide $48 \mathrm{SC}$ ), $\mathrm{T}_{9}$ (spray with spinosad $45 \mathrm{SC}$ ), $\mathrm{T}_{8}$ (seed treated with thiamethoxam $30 \mathrm{FS}$ ), $\mathrm{T}_{7}$ (seed treated with imidacloprid $48 \mathrm{FS}$ ) and $\mathrm{T}_{11}$ (spray with chlorantraniliprole 18.5 SC) with cost-befit ratio of Rs. 1.30, Rs. 1.19, Rs. 1.18, Rs. 1.16, Rs. 1.01, Rs. 0.74, Rs. 0.62, Rs. 0.59 and Rs. 0.48 and Rs. 0.44 per rupee invested, respectively. The relative performance of the treatment terms of net profit generated per hectare in descending order was as follows.

$$
T_{2}>T_{3}>T_{6}>T_{4}>T_{5}>T_{1}>T_{10}>T_{9}>T_{8}>T_{7}>T_{11}
$$

Seed treated with imidacloprid 48 FS and spray flubendiamide $48 \mathrm{SC}$ at 50 per cent flowering stage $\left(\mathrm{T}_{2}\right)$ which give highest net profit Rs. 10,678 and highest costbenefit ratio $(1: 1.42)$ among of all treatments.

\section{CONCLUSION}

In a nutshell, seed treated with imidacloprid 48 FS was found highly effective against sucking insect pests via. jassid, thrips and whitefly in greengam. At 50 per cent flowering stage, spray of flubendiamide $48 \mathrm{SP}$ and chlorantraniliprole 18.5 SC insecticides both was significantly reduced population of spotted pod borer (Maruca vitrata) and gram pod borer (Helicoverpa armigera) in greengram. The seed treated with imidacloprid 48 FS and thiomethoxam 30 FS followed by spray with spinosd 45 SC, flubendiamide 48 SC and chlorantraniliprole $18.5 \mathrm{SC}$ at 50 per cent flowering stages provides the higher seed yield. However, highest net profit and cost-benefit ratio was found in seed treated with imidacloprid 48 FS and spray of flubendiamide at 50 per cent flowering stage in green gram.

\section{REFERENCES}

Anusha, C., Natikar, P.K. and Balikai, R.A. (2016). Insect pests of cowpea and their management - A review. Journal of Experimental Zoology, India. 19(2): 63-642. Retrieved from http://www.connectjournals.com/jez.

Biswas, A. and Bhunia, C.K. (2009). Integrated management of mungbean yellow mosaic virus (MYMV) disease. Pestology. 33(1): 19-23.

Duncan, D.B. (1955). Multiple Range and Multiple F Tests. Biometrics. 11(1): 1-42. https://doi.org/10.2307/3001478

Jain, A.K., Yadava, H.S. and Gupta, J.C. (1995). Grain yield and its components as affected by yellow mosaic virus in black gram [Vigna mungo (L.) Hepper]. Annals of agricultural research. 16: 364-366.

Khutwad, D.S., Nakat, R.V. and Chavan, B.P. (2002). Seed dressers and foliar sprays on sucking pests of green gram, [Vigna radiata (L.) Wilczek]. Pestology. 26: 57-59.

Kumar, C.T.A. and Shivaraju, C. (2009). Evaluation of newer insecticide molecules against pod borers of black gram. Karnataka journal of agricultural sciences. 22(3): 521523. Retrieved from https://www.cabdirect.org/cabdirect/ abstract/20103004263.

Lal, S.S. and Sachan, J.N. (1987). Recent advances in pest management in pulses. Indian farm. 37(7): 29-32.

Mahalakshmi, M.S. and Rao, C.V.R., Adinarayana, M., Babu, J.S., Rao, Y.K. (2013). Evaluation of coragen ( DPX-E2Y45) against legume pod borer, Maruca vitrata (Geyer) ( lepidoptera /: pyralidae ) on blackgram. International journal of plant, animal and enviromental sciences. 3(4): 51-54.

Mahalakshmi, M.S., Sreekanth, M., Adinarayana, M. (2018). Avoidable yield loss in greengram due to major insect pests through insecticide spray schedules under field conditions. Journal of Entomology and Zoology Studies. 6(2): 1136-1139.

Mallikarjuna, J., Kumar, C.T.A., Rashmi, M.A. (2009). Field evaluation of indigenous materials and newer insecticide molecules against pod borers of dolichos bean. Karnataka Journal of Agricultural Sciences. 22(617): 2009.

Panduranga, G.S., Vijayalakshmi, K. and Reddy, K.L. (2011). Evaluation of insecticides for management of Bemisia tabaci and MYMV disease in mung bean [Vigna radiata (L.) Wilczek]. Annals of Plant Protection Sciences. 19(2): 295-298.

Ramachandran, P. (2006). The double burden of malnutrition in India. In The double burden of malnutrition. Case studies from six developing countries. (Vol. 84, p. 99). Retrieved from http://www.ncbi.nlm.nih.gov/pubmed/19172986.

Salam, S.A. (2005). Studies on Mungbean Yellow Mosaic Virus Disease on Greengram. (Master thesis, University of Agricultural Sciences, Dharwad). Retrieved from http://krishikosh. egranth.ac.in/handle/1/81649.

Steel, R.G.D. and Torrie, J.H. (1980). Principles and procedures of statistics, a biometrical approach. Tokyo: McGraw-Hill Kogakusha, Ltd. 